\title{
PEMODELAN DAN ANALISA STRUKTUR BAWAH PERMUKAAN DAERAH PROSPEK PANASBUMI KEPAHIANG BERDASARKAN METODE GAYABERAT
}

\author{
Roy Bryanson Sihombing*, Rustadi \\ J1 Prof. Dr. Sumantri Brojonegoro No.1 Bandar Lampung 35145 \\ Jurusan Teknik Geofisika, FT UNILA \\ *e-mail: roybsihombing@gmail.com
}

\begin{abstract}
ABSTRAK
Telah dilakukan penelitian di daerah Kepahiang menggunakan data gayaberat dengan tujuan mengidentifikasi patahan berdasarkan analisis Second Vertical Derivative (SVD) dan menafsirkan struktur bawah permukaan berdasarkan model inversi 3D dari anomali Bouguer dan anomali residual. Daerah penelitian memiliki anomali Bouguer antara $38 \mathrm{mGal}-74 \mathrm{mGal}$, dimana nilai anomali Bouguer tinggi memiliki rentang nilai $63,2 \mathrm{mGal}-74 \mathrm{mGal}$ yang berada di arah barat daya daerah penelitian. Sedangkan nilai anomali Bouguer rendah memiliki rentang nilai $38 \mathrm{mGal}-47 \mathrm{mGal}$ yang berada di arah utara daerah penelitian. Untuk mengetahui keberadaan struktur patahan di daerah penelitian, dilakukan filtering Second Vertical Derivative (SVD) pada peta anomali Bouguer, Regional dan Residual. Pola struktur patahan ditunjukkan dengan kontur bernilai nol dan diapit kontur tinggi dan rendah. Dari hasil analisis SVD anomali Bouguer lengkap dan SVD anomali residual terdapat 8 (delapan) patahan, sedangkan dari SVD anomali regional terdapat 4 (empat) patahan. Pemodelan inversi 3D anomali residual dilakukan untuk membuktikan keberadaan patahan yang dianalisis berdasarkan filtering Second Vertical Derivative (SVD). Berdasarkan hasil inversi 3D anomali residual didapatkan satu (1) reservoar di arah utara daerah penelitian dan dua (2) di arah barat daerah penelitian dengan kontras densitas dari $-0,0719356 \mathrm{gr} / \mathrm{cm}^{3}$ sampai $-0,236053 \mathrm{gr} / \mathrm{cm}^{3}$ dengan kedalaman dari 0 meter sampai 4.705 meter.
\end{abstract}

\begin{abstract}
Research has been conducted in Kepahiang area using gravity data with the aim of identify faults based on analysis of the Second Vertical Derivative (SVD) and interpreting structure sub-surface of the based on 3D inverse modelling from Bouguer anomaly and residual anomaly. The research area have an Bouguer anomaly between $38 \mathrm{mGal}-74 \mathrm{mGal}$, where the high Bouguer anomaly value has a value range of $63,2 \mathrm{mGal}-74 \mathrm{mGal}$ located in the southwest direction of the research area. Whereas the low Bouguer anomaly value has a range of values $38 \mathrm{mGal}-47 \mathrm{mGal}$ located in the north of the research area. To know the existence of fault structure in research area, conducted filtering Second Vertical Derivative (SVD) on the map Bouguer anomaly, regional and residual. The structure faulting is shown with contour of zero and between the contours of high and low. From the analysis of SVD complete anomaly Bouguer and SVD residual anomaly there are 8 (eight) faulting, while from SVD regional anomaly there are 4 (four) fault. 3D inversion modeling of the residual anomaly was done to prove the existence of the fault analyzed based on filtering Second Vertical Derivative (SVD). Based on the results of inversion 3D residual anomaly been gained one (1) reservoir in a northern direction research area and two (2) in the direction of west the research area by a contrast the density of $0,0719356 \mathrm{gr} / 33^{3}$ until $-0,236053 \mathrm{gr} / 33^{3}$ with a depth of 0 meters up to 4.705 meters.
\end{abstract}

Keywords: 3D inverse modelling, geothermal, gravity, Kepahiang, SVD. 


\section{PENDAHULUAN}

Panasbumi (geothermal) adalah sumber daya alam berupa air panas atau uap yang terbentuk di dalam reservoir bumi melalui pemanasan air bawah permukaan oleh batuan panas. Sekitar $40 \%$ cadangan energi panasbumi (geothermal) dunia terletak di bawah tanah Indonesia, maka negara ini diperkirakan memiliki cadangan-cadangan energi geotermal terbesar di dunia dan karena itu memiliki potensi tinggi untuk sumber energi terbarukan.

Metode geofisika dimanfaatkan dalam menentukan konfigurasi struktur geologi dan komposisi bawah permukaan dengan menggunakan parameter fisika. Salah satu metode yang sering digunakan adalah metode gayaberat. Metode gayaberat digunakan untuk mengetahui kondisi bawah permukaan bumi dengan cara mengukur variasi medan gayaberat bumi. Adanya suatu sumber yang berupa suatu massa di bawah permukaan akan menyebabkan terjadinya gangguan medan gayaberat, gangguan medan gayaberat ini disebut sebagai anomali gayaberat (Suhadiyatno, 2008).

Penelitian ini menggunakan metode gayaberat yang dilakukan di daerah panasbumi Kepahiang, Provinsi Bengkulu. Dimana daerah panasbumi Kepahiang secara tektonik berada pada busur magmatik yang terletak di sebelah barat Pulau Sumatera. Dalam eksplorasi panasbumi, metode gayaberat dapat mendeteksi perbedaan densitas batuan di bawah permukaan yang membentuk suatu sistem panasbumi. Pada penelitian ini dilakukan pemodelan inversi 3D anomali Bouguer dan melakukan filter Second Vertical Derivative (SVD) anomali Bouguer, anomali Bouguer residual untuk mengetahui struktur patahan dan model 3D sistem panasbumi beserta karakteristik sistem panasbumi daerah Kepahiang.

\section{TINJAUAN PUSTAKA}

\subsection{Lokasi Daerah Penelitian}

Kabupaten Kepahiang memiliki luas wilayah $\pm 66.500 \mathrm{Ha}$, yang terletak pada posisi $101^{\circ} 55^{\prime} 19^{\prime}$ ' $-103^{\circ} 01^{\prime} 29$ Bujur Timur dan $02^{\circ} 43^{\prime} 07^{\prime}$ ' - 03'46' 48', Lintang Selatan seperti yang tertera pada Gambar 1.

\subsection{Geologi Regional}

Secara garis besar Komplek Gunung api Kaba terbagi menjadi 2 bagian, yaitu produk erupsi Kaba Tua dan produk erupsi Kaba Muda yang dikelilingi oleh produk gunungapi lain, seperti Bukit Lumut di barat laut, Taba Penanjung di barat daya dan Bukit Malintang di tenggaranya. Catatan sejarah menyatakan bahwa umur dari masing - masing produk vulkanik adalah Kuarter Awal, sampai saat ini Gunung Kaba masih menunjukkan aktivitas vulkanik dan kegempaan.

Sejarah pembentukan Gunung Kaba diawali pada Kuarter Awal, berupa erupsi yang bersifat eksplosif yang menghasilkan produk lava Kaba Tua I hingga III dan produk piroklastik aliran maupun jatuhan. Seiring dengan aktivitas tektonik yang berkembang di daerah Sumatera pada Kala tersebut, di daerah Gunung Kaba mengalami letusan hebat yang membentuk rim kaldera seperti yang ditunjukkan pada peta di bagian barat dan timur Komplek Kaba. Data tersebut didukung dengan ditemukannya pumis dan skorea berukuran bom hingga lapili di daerah Kampung Bogor dan sekitarnya. Pelamparan skoria dalam jumlah yang luas juga mendukung akan terbentuknya letusan kuat dengan volume piroklastik yang cukup besar.

Setelah terjadi letusan besar yang membentuk pola rim kaldera terjadi kekosongan dan rekahan yang cukup intensif. Sesar - sesar yang berarah barat laut - tenggara seperti sesar Kaba dan sesar Sempiang memfasilitasi terjadinya erupsi magmatik berikutnya dari mulai produk Bukit Itam, Bukit 1960, Biring, Salojuang dan Gunung Kaba yang berarah hampir 
barat - timur $\left(63^{\circ}\right)$ sesuai dengan arah sesar Itam. Masing masing produk tersebut berada di dalam rim kaldera Komplek Kaba sedangkan sesar Bandung Baru yang berkembang pada tubuh Kaba bagian selatan memfasilitasi munculnya kerucut kerucut sinder seperti yang dijumpai di daerah Kepahiang Indah.

Catatan erupsi terakhir yang diperoleh dari data Direktorat Vulkanologi menyatakan bahwa pada tahun 1951 terjadi letusan yang menghasilkan kawah Volgesang di sisi timur Komplek Kaba. Tahun 2002 terjadi letusan abu dan hidrotermal erupsi di Kawah Kaba Besar. Sampai saat ini tidak ditemukan adanya pembentukan lava baru sebagai ciri dari aktivitas magmatik, tapi masih terjadi letusan - letusan hidrotermal kecil di Kawah Kaba Besar. Hal tersebut mencerminkan telah terbentuknya sistem hidrotermal di kawasan tersebut.

Data geologi daerah panasbumi Kepahiang menunjukkan adanya batuan yang memiliki sifat impermeable dengan kandungan mineral lempung jenis montmorilonit, kaolinit yang cukup tinggi pada daerah alterasi di sekitar manifestasi Air Sempiang. Batuan alterasi yang terbentuk merupakan tipe argilik hingga argilik lanjut. Alterasi tersebut muncul pada aliran piroklastik dan lava produk Gunung Kaba. Batuan penudung ini berada pada zona struktur sesar Sempiang yang berarah hampir utara selatan. Selain data alterasi, kemungkinan lainnya yang dapat diinterpretasikan sebagai batuan penudung adalah lava muda produk Kaba yang masif dan belum terkekarkan secara kuat. Data geologi daerah panasbumi Kepahiang ditunjukkan pada Gambar 2.

\subsection{Statigrafi}

Statigrafi daerah penyelidikan disusun oleh hasil kegiatan 4 pusat sumber erupsi yang terdiri dari: G. Taba Penanjung, G. Malintang, G. Danau Mas dan G. Kaba.

Komplek G. Kaba sedikitnya mempunyai 8 pusat letusan (titik erupsi) dari tua ke muda terdiri dari: G. Kaba Tua,
Kerucut-kerucut sinder, G. Biring, G. Bukit Itam, G. Bukit 1960, G. Salojuang, G. Penyeluan dan G. Kaba Muda.

Berdasarkan pembagian mandala geologi Tersier Pulau Sumatera, daerah Kepahiang terletak di dalam busur magmatik dan nama lajur yang digunakan adalah Lajur Barisan. Stratigrafi Daerah Kepahiang dapat dibagi menjadi dua tahap, yaitu urutan Tersier dan kuarter.

1. Stratigrafi Tersier

a. Satuan tertua adalah Formasi Seblat (Toms), berumur Oligosen Tengah Miosen Akhir. Bagian bawah terdiri dari batu pasir yang sebagian karbonan, batu pasir tufan kayu terkersikan dan lensa-lensa konglomerat. Bagian tengah terdiri atas selingan batu gamping dan batu lempung. Bagian atas terdiri dari serpih dengan sisipan batu lempung tufan, napal dan konglomerat. Formasi Seblat diendapkan di lingkungan laut dengan kondisi turbidit

b. Formasi Hulu Simapang (Tomh) berumur Oligosen Akhir - Miosen Tengah. Formasi ini ditemukan setempat di bagian selatan Kepahiang. Formasi Hulu Simpang terdiri dari lava, breksi gunungapi dan tuf, khas terkhloritkan dan terpropiltkan dengan mineralisasi sulfida dan urat-urat kuarsa. Lava andesit basal fenokris plagioklas sebagian terubah menjadi serisit di dalam masa dasar yang mengandung hornblenda. Breksi gunungapi terpilah buruk, komponen menyudut bersusun andesit-basal. Tuf umumnya berlapis baik, terubah kuat, epidotsi dan kloritasi dengan pirit. Setempat berupa tuf padu. Diendapkan di lingkungan peralihan, darat-laut dangkal.

c. Formasi Gumai (Tmg), berumur Miosen Tengah. Formasi Gumai bagian bawah terdiri atas perselingan serpih, napal dan batu lempung dengan bintil batu lanu dan batu gamping: bagian tengah terdiri atas serpih dan batu lempung dengan 
sisipan batu lanu dan batu pasir tufan: bagian atas terdiri atas serpih dengan sisipan batu lempung gampingan. Formasi Gumai diendapkan di lingkungan neritik.

d. Batuan Terobosan Miosin Diorit (TmdI), batuan ini menerobos Formasi Hulu Simpang dan ditindih oleh batuan gunungapi Plistosen. Batuan ini ditafsirkan berumur Miosen Tengah dan merupakan bagian dari jalur pluton regional bersusun diorit yang menerobos sepanjang lereng barat Pegunungan Barisan. Di daerah Kepahiang batuan terobosan Diorit ditemukan setempat dibagian utarabarat.

2. Stratigrafi Kuarter

Satuan batuan yang ada dalam runtunan. Stratigrafi Kuarter adalah sebagai berikut:

a. Batuan Breksi Gunungapi (Qhv) berumur holosen, terdiri dari breksi gunungapi, tuf bersusun andesit-basal. Daerah Kepahiang sebagian besar didominasi oleh Batuan Breksi Gunungapi.

b. Satuan Batuan Gunungapi (Qv) berumur Plistosen -Holosen, terdiri dari lava bersusun andeist sampai basal, tuf dan breksi lahar.

\subsection{Geomorfologi}

Geomorfologi daerah penyelidikan dikelompokkan menjadi empat satuan geomorfologi, terdiri dari: Satuan geomorfologi Puncak Kaba, Satuan geomorfologi Tubuh (Taba Penanjung, Malintang dan Kaba), Satuan geomorfologi Kaki Kaba dan Satuan geomorfologi Pedataran.

\subsection{Manifestasi Panasbumi}

Manifestasi panas bumi daerah Kepahiang terdiri dari fumarol, mata air panas, batuan ubahan dan solfatara. Terdapat dua kelompok manifestasi yaitu:

a. Kelompok Sempiang terdapat di hulu sungai airputih daerah Bukit Itam berada pada koordinat UTM zona 48 belahan bumi selatan dengan $X$ : $234.715 \mathrm{mT}$ dan $Y$ : $9.606 .757 \mathrm{mS}$ dengan ketinggian $1.286 \mathrm{~m} \mathrm{dpl}$. Terdiri dari pemunculan mata air panas, fumarol, dan batuan ubahan.

b. Kelompok Babakan Bogor dijumpai di kampung Babakan Bogor pada koordinat UTM zona 48 belahan bumi selatan dengan $X: 229.261 \mathrm{mT}$ dan $Y$ : $9.600 .988 \mathrm{mS}$ pada ketinggian 573 604 mdpl. Manifestasi berupa pemunculan 2 mata air panas dengan temperatur $41,3^{\circ} \mathrm{C}$. Selain itu di Babakan Bogor, terdapat mata air dingin, muncul pada elevasi $619 \mathrm{~m}$ dpl, temperatur $30,1^{\circ} \mathrm{C}$.

\section{TEORI DASAR}

\subsection{Percepatan Gravitasi}

Newton juga mendefinisikan hubungan antara gaya dan percepatan. Hukum Newton II tentang gerak menyatakan gaya sebanding dengan perkalian massa benda dengan percepatan yang dialami benda tersebut.

$$
\mathrm{g}=\frac{F}{m}=G \frac{M \cdot m}{m \cdot r^{2}}=G \frac{M}{r^{2}}
$$

dimana, $g$ : Percepatan gaya tarik bumi, $M$ : Massa bumi, $m$ : Massa benda, $F$ : Gaya berat, $r$ : Jari-jari bumi (Octonovrilna, 2009).

\subsection{Complete Bouguer Anomali (CBA)}

Complete Bouguer Anomali (CBA) merupakan selisih antara nilai gayaberat pengamatan dengan gayaberat teoritik yang didefinisikan pada titik pengamatan bukan pada bidang referensi, baik elipsoid maupun muka laut rata-rata. Complete Bouguer Anomali (CBA) diberikan dalam persamaan (Robinson, 1988):

$$
C B A=g_{\text {obs }}-g_{\varphi}+F A C-B C+T C
$$

dimana, CBA : Complete Bouguer Anomali, $g_{o b s}$ : Gayaberat observasi, $g_{\varphi}$ : Gayaberat normal/ teoritis pada lintang, $F A C$ : Koreksi udara bebas terhadap ketinggian dari muka laut, $B C$ : Koreksi Bouguer, TC: Koreksi medan, $\rho$ : Rapat massa, $h$ : Tinggi (meter). 


\subsection{Analisis Spektrum}

Analisa spektrum dilakukan untuk mengestimasi lebar jendela dan mengestimasi kedalaman dari anomali gayaberat. Spektrum diturunkan dari potensial gayaberat yang teramati pada suatu bidang horizontal dimana transformasi fouriernya sebagai berikut (Blakely, 1995):

$$
F(U)=\gamma \mu F\left(\frac{1}{r}\right) \text { dan } F\left(\frac{1}{r}\right)=2 \pi \frac{e^{|k|\left(z_{o}-z^{\prime}\right)}}{|k|}
$$

dimana, $U$ : Potensial gayaberat, $\gamma$ : Konstanta gayaberat, $\mu$ : Anomali gayaberat, $r$ : Jarak.

\subsection{Metode Moving Average}

Moving average merupakan peratarataan dari data anomali gayaberat. Hasil dari metode ini adalah nilai anomali regional, dan untuk anomali residual diperoleh dari selisih antara anomali Bouguer dengan nilai anomali regionalnya (Diyanti, 2014).

Secara sistematis persamaan moving average untuk kasus 1-D adalah sebagai berikut:

$$
\Delta g_{r e g}=\frac{\Delta \mathrm{g}(\mathrm{i}-\mathrm{n})+\cdots+\Delta \mathrm{g}(\mathrm{i})+\cdots+\Delta \mathrm{g}(\mathrm{i}+\mathrm{n})}{\mathrm{N}}
$$

Perata-rataan dalam jendela $5 \times 5$ pada data 2 (dua) dimensi diberikan persamaan:

$$
\Delta g_{R}=\frac{1}{25}\left[\left(\Delta g_{(B 1)}+\Delta g_{(B 2)}+\cdots+\Delta g_{(B 25)}\right)\right]
$$

(Robinson, 1988).

\subsection{Analisa Derivative}

Analisa Derivative digunakan untuk menentukan batas dan mengetahui jenis patahan. Untuk mendapatkan hal tersebut maka dilakukan First Horizontal Derivative (FHD) dan Second Vertical Derivative (SVD) dari lintasan yang dibuat dalam peta anomali Bouguer atau peta anomali regional ataupun peta anomali residual yang selanjutnya dibuat penampangnya.

\subsubsection{Metode Horizontal Gradient}

First Horizontal Derivative (FHD) atau turunan pertama mempunyai nama lain yaitu Horizontal Gradient (HG). Horizontal gradient dari anomali gayaberat yang disebabkan oleh suatu body cenderung untutk menunjukkan tepian dari body-nya tersebut. Jadi metode horizontal gradient dapat digunakan untuk menentukan lokasi batas kontak densitas horizontal dari data gayaberat (Cordell, 1979).

Karena model sintetik dalam bentuk penampang hanya dalam arah $x$, sehingga rumus FHD menjadi lebih praktis, yaitu:

$$
F H D=\sqrt{\left(\frac{\partial g}{\partial x}\right)^{2}}
$$

\subsubsection{Second Vertical Derivative (SVD)}

Second Vertical Derivative (SVD) bersifat sebagai High Pass Filter sehingga dapat menggambarkan anomali residual yang berasosiasi dengan struktur dangkal yang dapat digunakan untuk mengidentifikasi jenis patahan turun, patahan naik atau patahan mendatar.

$$
S H D=\left(\frac{\partial^{2} g}{\partial^{2} x}\right)
$$

Arah kemiringan kurva SVD dapat menunjukan jenis sesar, diketahui dari perbandingan antara harga mutlak SVD maksimum dan minimum yang diberikan oleh:

Untuk patahan naik $\left(\frac{\partial^{2}(\Delta g)}{\partial x^{2}}\right)_{\text {maks }}<\left|\left(\frac{\partial^{2}(\Delta g)}{\partial x^{2}}\right)\right|_{\text {min }}$ Untuk patahan turun $\left(\frac{\partial^{2}(\Delta g)}{\partial x^{2}}\right)_{\text {maks }}>$ $\left|\left(\frac{\partial^{2}(\Delta g)}{\partial x^{2}}\right)\right|_{\min }$

Untuk patahan mendatar $\left(\frac{\partial^{2}(\Delta g)}{\partial x^{2}}\right)_{\operatorname{maks}}=\left|\left(\frac{\partial^{2}(\Delta g)}{\partial x^{2}}\right)\right|_{\min }$

\subsection{Pemodelan Inversi 3D}

Proses inversi adalah suatu proses pengolahan data lapangan yang melibatkan teknik penyelesaian matematika dan statistik untuk mendapatkan informasi yang berguna mengenai distribusi sifat fisis bawah permukaan. Di dalam proses inversi, kita melakukan analisis terhadap data lapangan dengan cara melakukan curve fitting (pencocokan kurva) antara model matematika dan data lapangan. Tujuan dari proses inversi adalah untuk mengestimasi parameter fisis batuan yang tidak diketahui sebelumnya (unkwown parameter), (Supriyatno, 2007). 


\subsection{Sistem Panasbumi (Geothermal System)}

Sistem panasbumi adalah suatu sistem yang memungkinkan terjadinya fluida dari daerah meteoric recharge ke dalam reservoar yang berada di atas sumber panas (heat source), (Torkis, 2012).

\section{METODOLOGI PENELITIAN}

\subsection{Tempat dan Waktu Penelian}

Pengolahan data dilakukan di laboratorium Jurusan Teknik Geofisika Fakultas Teknik Universitas Lampung.

Adapun alat dan bahan yang digunakan dalam penelitian ini adalah: peta anomali Bouguer Kepahiang, peta geologi Kepahiang, peta topografi Kepahiang, software yang digunakan dalam penelitian ini antara lain Global Mapper 12, Surfer12, Microsoft Office Exel, Numeri, Google Map dan Grav3D.

\subsection{Prosedur Penelitian}

Adapun prosedur pelaksanaan penelitian ini, yaitu:

\subsubsection{Pengolahan Data}

Data gayaberat yang diolah adalah data gayaberat sekunder dalam bentuk peta kontur anomali Bouguer dengan format raster.

\subsubsection{Filtering Data Anomali}

\section{a. Analisis Spektrum}

Pada proses ini peta anomali Bouguer daerah penelitian yang telah didapat kemudian dilakukan slice dengan 4 lintasan lalu ditransformasi fourrier dengan menggunakan software Numeri untuk digunakan sebagai analisis spektrum untuk menentukan nilai lebar jendela, dimana nilai lebar jendela yang diperoleh yaitu 19 x 19 .

b. Pemisahan Anomali Regional -

Residual

Pada proses ini anomali gayaberat difilter dengan menggunakan metode moving average dengan menggunakan filter Elkins, frekuensi yang kemudian diubah menjadi lebar jendela.
Peta penyebaran anomali regional merupakan tampilan hasil pengolahan atau hasil penyaringan dari data anomali Bouguer. Penyaringan ini dilakukan untuk menunjukan efek atau respon anomali dalam. Peta penyebaran anomali residual merupakan tampilan data hasil pengurangan data anomali Bouguer terhadap anomali regional. Dimana data anomali residual mempunyai respon anomali dangkal.

c. Analisis Second Vertical Derivatif (SVD)

Analisis second vertical derivatif (SVD) dilakukan pada peta anomali Bouger, peta anomali regional dan peta anomali residualnya sehingga didapatkan nilai anomali nol yang diindikasikan sebagai patahan.

Dimana pada anomali residual, peta SVD akan menunjukkan patahan yang relatif dangkal sedangkan pada anomali regional dapat menunjukkan patahan yang relatif lebih dalam.

d. Pemodelan Bawah Permukaan

Dari peta anomali Bouguer dan peta anomali residual dilakukan permodelan 3 dimensi dengan metode inverse modelling untuk melihat lebih jelas struktur bawah permukaan daerah penelitian berupa sebaran densitasnya, pemodelan inversi pada penelitian ini dilakukan menggunakan Grav3D.

\section{HASIL DAN PEMBAHASAN 5.1.Topografi}

Daerah penelitian ini berada di daerah Kabupaten Kepahiang Provinsi Bengkulu dengan luas daerah survei sekitar (12 x 8) $\mathrm{km}$. Nilai topografi di daerah Kepahiang berkisar antara $500-1.600$ meter seperti pada Gambar 16. Daerah tertinggi berada di sekitar arah utara daerah penelitian yang memiliki nilai topografi tertinggi yaitu sekitar 1.596 meter yang kemungkian merupakan daerah vulkanik. Sedangkan di sekitar arah barat daya daerah penelitian merupakan memiliki nilai topografi yang rendah. 


\subsection{Anomali Bouguer}

Anomali Bouguer merupakan selisih antara nilai gayaberat pengamatan dengan gayaberat teoritik pada titik pengamatan.

Peta anomali Bouguer dan sebaran titik pengukuran gayaberat yang diperlihatkan pada Gambar 17, menunjukkan bahwa daerah penelitian memiliki nilai anomali yang bervariasi yaitu berkisar antara $38 \mathrm{mGal}-74 \mathrm{mGal}$. Dimana nilai anomali Bouguer tinggi memiliki rentang nilai sekitar $63,2 \mathrm{mGal}-$ $74 \mathrm{mGal}$ yang berada di arah barat daya daerah penelitian. Nilai anomali tinggi dapat diperkirakan sebagai daerah yang batuannya bersifat lebih massive. Sedangkan nilai anomali Bouguer rendah memiliki rentang nilai $38 \mathrm{mGal}-47 \mathrm{mGal}$ yang berada di arah utara daerah penelitian.

\subsection{Analisis Spektrum}

Pada penelitian ini, transformasi Fourier dilakukan menggunakan software Numeri. Analisis spektrum pada penelitian ini dilakukan pada 4 (empat) lintasan dengan nilai jarak spasi adalah $250 \mathrm{~m}$.

Dari masing-masing analisis spektrum yang telah dilakuan, diperoleh tren regional dan tren residual yang berbedabeda dari tiap lintasan, hal ini dapat terlihat pada Tabel 4.

\subsection{Moving Average}

Moving average merupakan peratarataan bergerak dari data anomali gayaberat. Metode ini digunakan dalam proses pemisahan anomali regional dan residual dengan filter frekuensi yang kemudian diubah menjadi lebar jendela.

\subsubsection{Anomali Regional}

Peta penyebaran anomali regional mempunyai respon anomali yang dalam. Gambar 23 merupakan peta anomali regional yang merupakan hasil dari filter moving average dengan jendela 19x19.

Nilai anomali berkisar antara $43 \mathrm{mGal}$ - 68 mGal. Dimana nilai anomali yang rendah berada di arah utara daerah penelitian yang memiliki nilai berkisar antara $43 \mathrm{mGal}$ sampai $49 \mathrm{mGal}$, hal ini mengindikasikan adanya litologi batuan yang memiliki nilai porositas yang tinggi atau densitas rendah. Sedangkan nilai anomali yang tinggi berada di arah tenggara dan arah barat daya daerah penelitian yang memiliki nilai berkisar antara $58 \mathrm{mGal}$ sampai $68 \mathrm{mGal}$. Pada arah timur daerah penelitian diduga sebagai sumber panas (heat source) karena memiliki nilai anomali gayaberat dan topografi yang tinggi.

\subsubsection{Anomali Residual}

Peta penyebaran anomali residual mempunyai respon anomali yang dangkal, dimana anomali ini merupakan tampilan data hasil pengurangan data anomali bouguer terhadap anomali regional.

Dari peta anomali residual yang ditunjukkan pada Gambar 24 terlihat bahwa adanya anomali rendah yang ditunjukkan oleh skala warna biru berada di arah utara dan arah barat daya daerah penelitian yang memiliki nilai berkisar antara -7 mGal sampai $-3,5$ mGal. Sedangkan anomali tinggi yang ditunjukkan oleh skala warna kuningmerah berada di bagian tengah dan arah barat daya daerah penelitian yang memiliki nilai berkisar antara $1 \mathrm{mGal}$ sampai 6,5 mGal.

\subsection{Second Vertical Derivative (SVD)}

Second Vertical Derivative (SVD) atau turunan kedua secara vertikal digunakan untuk menentukan batas-batas struktur yang ada di daerah penelitian. Kontur anomali yang bernilai nol ditunjukkan dengan garis kontur warna merah, kontur nol yang diapit oleh nilai anomali tinggi dan rendah yang mengindikasikan adanya suatu struktur patahan di daerah tersebut.

Gambar 25 menunjukkan peta anomali Bouguer lengkap yang telah dilakukan filter Second Vertical Derivatif (SVD). Nilai SVD Bouguer lengkap memiliki kontras nilai sekitar -3 sampai 4. Pada peta SVD anomali 
Bouguer lengkap diindikasikan terdapat 8 (delapan) patahan yaitu 1 (satu) patahan terletak di arah barat daya, 3 (tiga) patahan terletak di arah barat yang di sekitar daerah tersebut terdapat manifestasi berupa 2 (dua) mata air panas, 1 (satu) patahan terletak di bagian tengah, 2 (dua) patahan di arah timur laut dan 1 (satu) patahan terletak di arah utara daerah penelitian atau terletak pada bagian selatan Gunung Kaba, dimana di sekitar daerah tersebut terdapat manifestasi berupa mata air panas dan fumarol.

Gambar 26 menunjukkan peta anomali Regional yang telah dilakukan filter Second Vertical Derivatif (SVD). Patahan pada peta kontur SVD anomali regional menunjukan patahan yang lebih dalam. Nilai SVD Regional memiliki kontras nilai sekitar $-0,45$ sampai $0,75 \mathrm{~m}$. Pada peta SVD anomali Regional diindikasikan terdapat 4 (empat) patahan. Patahan yang pertama terletak di arah barat daya yang di sekitar daerah tersebut terdapat manifestasi berupa 2 (dua) mata air panas, 1 (satu) di bagian tengah yang sejajar dengan arah sesar sumatera, 1 (satu) di arah utara yang di sekitar daerah tersebut terdapat manifestasi berupa mata air panas dan fumarol, serta 1 (satu) berada di arah timur laut daerah penelitian.

Gambar 27 menunjukkan peta anomali Residual yang telah dilakukan filter Second Vertical Derivatif (SVD). Peta ini memiliki gambaran yang hampir sama dengan peta $S V D$ anomali Bouguer lengkap yang memiliki kontras nilai sekitar $-2,5$ sampai $4 \mathrm{mGal} / \mathrm{m}^{2}$. Perbedaan dari peta SVD anomali Bouguer lengkap dengan peta SVD anomali residual adalah pada nilai anomali yang lebih dangkal. Pada peta SVD anomali Residual diindikasikan terdapat 8 (delapan) patahan yaitu 1 (satu) patahan terletak di arah barat daya, 3 (tiga) patahan terletak di arah barat yang di sekitar daerah tersebut terdapat manifestasi berupa 2 (dua) mata air panas, 1 (satu) patahan terletak di bagian tengah, 2 (dua) patahan di arah timur laut dan 1 (satu) patahan terletak di arah utara daerah penelitian atau terletak pada bagian selatan Gunung Kaba, dimana di sekitar daerah tersebut terdapat manifestasi berupa mata air panas dan fumarol.

\subsection{Pemodelan Inversi 3D Anomali Bouguer}

Hasil pemodelan inversi 3D anomali Bouguer pada Gambar 28 menunjukkan sebaran kontras densitas daerah penelitian yang dilihat dari arah barat, timur, selatan dan utara pada ketinggian 1.295 meter sampai -9.705 meter dan memiliki kontras densitas dari $-0,0546 \mathrm{gram} / \mathrm{cm}^{3}$ sampai $1,17 \mathrm{gram} / \mathrm{cm}^{3}$. Nilai kontras densitas rendah ditunjukkan oleh warna biru tua dengan nilai sekitar -0,0546 gram $/ \mathrm{cm}^{3}$ sampai $0,15 \mathrm{gram} / \mathrm{cm}^{3}$. Sedangkan nilai kontras densitas tinggi ditunjukkan oleh warna merah dengan nilai sekitar 0,968 gram $/ \mathrm{cm}^{3}$ sampai $1,17 \mathrm{gram} / \mathrm{cm}^{3}$.

\subsection{Analisis Struktur Patahan Berdasarkan Model 3D dan Peta SVD}

Anomali residual menunjukkan struktur bawah permukaan yang memiliki kedalaman yang rendah atau dangkal. Filter SVD dilakukan pada anomali residual bertujuan untuk menemukan patahan dangkal sehingga dilakukan perbandingan antara SVD Residual dengan model inversi Residual.

Gambar 29 menunjukkan peta SVD anomali residual dan model 3D anomali residual yang dilihat dari arah barat, dimana terdapat 2 (dua) patahan yang terletak di arah barat dan barat daya daerah penelitian. Untuk melakukan analisis patahan pada model inversi dilakukan cutoff pada koordinat UTM X 230000. Dari hasil penelitian antara peta SVD residual dengan model inversinya didapat kesamaan struktur patahan pada arah barat dan barat daya daerah penelitian, dimana 2 (dua) patahan tersebut mencapai kedalaman dari 200 meter sampai 1.700 meter. 
Gambar 30 menunjukkan peta SVD anomali residual dan model 3D anomali residual yang dilihat dari arah selatan, dimana terdapat 4 (empat) patahan yang terletak di arah barat dan bagian tengah daerah penelitian. Untuk melakukan analisis patahan pada model inversi dilakukan cut-off pada koordinat UTM Y 9601350. Dari hasil penelitian antara peta SVD residual dengan model inversinya didapat kesamaan struktur patahan pada arah barat daya daerah penelitian, dimana 4 (empat) patahan tersebut mencapai kedalaman dari 200 meter sampai 1.700 meter.

Gambar 31 menunjukkan peta SVD anomali residual dan model 3D anomali residual yang dilihat dari arah utara, dimana terdapat 1 (satu) patahan yang terletak di arah utara daerah penelitian. Dari hasil penelitian antara peta SVD Residual dengan model inversinya didapat kesamaan struktur patahan pada utara daerah penelitian, dimana 1 (satu) patahan tersebut mencapai kedalaman sekitar 200 meter.

Gambar 32 menunjukkan peta SVD anomali residual dan model 3D anomali residual yang dilihat dari arah selatan, dimana terdapat 2 (dua) patahan yang terletak di arah timur laut daerah penelitian. Untuk melakukan analisis patahan pada model inversi dilakukan cutoff pada koordinat UTM X 239000. Dari hasil penelitian antara peta SVD residual dengan model inversinya didapat kesamaan struktur patahan pada bagian tengah daerah penelitian, dimana 1 (satu) patahan tersebut mencapai kedalaman dari 200 meter sampai 3.200 meter.

\subsection{Analisis Sistem Panasbumi}

Suatu prospek panasbumi memiliki beberapa kriteria agar dapat disebut suatu sistem panas bumi yang baik yaitu: sumber panas (heat source), reservoar, lapisan tudung (cap rock) dan suplai air (fluida).

Data anomali residual digunakan dalam proses pemodelan inversi yang diharapkan dapat memperlihatkan sumber anomali dangkal yang ada. Model inversi 3D hasil inversi dari anomali residual daerah penelitian dapat dilihat pada Gambar 33.

Reservoar panasbumi merupakan batuan yang memiliki prosositas dan permeabilitas yang baik sehingga fluida dapat terakumulasi untuk dipanaskan oleh sumber panas. Kontras densitas dari -0,236 $\mathrm{gr} / \mathrm{cm}^{3}$ sampai $0,0989 \mathrm{gr} / \mathrm{cm}^{3}$ dengan kedalaman dari 0 meter sampai 4.705 meter. Densitas rendah berwarna biru muda yang memiliki kontras densitas dari $0,0719356 \mathrm{gr} / \mathrm{cm}^{3}$ sampai $-0,236053$ $\mathrm{gr} / \mathrm{cm}^{3}$ diduga sebagai reservoir panasbumi, dimana terdapat 2 (dua) manifestasi di daerah sekitar yang diduga sebagai reservoar dapat dilihat pada Gambar 34.

Telah dilakukan slice di daerah penelitian seperti yang ditunjukkan pada Gambar 35. Dari gambar dapat dilihat lapisan pada sistem panasbumi daerah penelitian, dimana reservoar terletak di arah utara daerah penelitian yang ditunjukkan dengan skala warna kuning serta lapisan-lapisan penunjang lainnya. Selain itu juga ditampilkan hasil slice dari inversi 3D daerah penelitian yang digunakan sebagai bahan perbandingan letak reservoar daerah penelitian.

\section{Kesimpulan}

Anomali Bouguer daerah penelitian mempunyai nilai dari $38 \mathrm{mGal}$ sampai 74 mGal dengan nilai anomali tinggi sekitar 63,2 mGal sampai $74 \mathrm{mGal}$ yang berada di arah barat daya daerah penelitian, sedangkan nilai anomali rendah sekitar 38 mGal sampai $47 \mathrm{mGal}$ yang berada di arah utara daerah penelitian.

Dari analisis spektrum didapatkan batas anomali regional berada pada kedalaman 3.000 meter.

Dari hasil analisis SVD anomali Bouguer lengkap dan SVD anomali Residual memiliki gambaran yang hampir sama sehingga memiliki jumlah patahan yang sama yaitu 8 (delapan) patahan, sedangakan pada SVD anomali Regional 
menunjukkan patahan yang lebih dalam yaitu memiliki 4 (empat) patahan.

Zona yang diduga sebagai reservoar memiliki kontras densitas dari $-0,072$ $\mathrm{gr} / \mathrm{cm}^{3}$ sampai $-0,236 \mathrm{gr} / \mathrm{cm}^{3}$ dengan kedalaman 0 meter sampai 4.705 meter.

\section{DAFTAR PUSTAKA}

Blakely, R. J. 1995. Potential Theory in Gravity \& Magnetic Application. Cambridge University Press.

Cordell, L., 1979. Gravimetric Expression of Graben in Santa Fe Country and Espanola Basin, New Mexico. New Mexico. Geol. Sot. Guidebook, $30^{\text {th }}$ Field Conf, 59-64.

Diyanti. 2014. Interpretasi Struktur Geologi Bawah Permukaan Daerah Leuwidamar Berdasarkan Analisis Spektral Data. Skripsi. Universitas Pendidikan Indonesia. Bandung.

Octonovrilna, L. dan I.P. Pudja. 2009. Analisa Perbandingan Anomaly Gravitasi dengan Persebaran Intrusi Air Asin. Jurnal Meteorologi dan Geofisika.

Robinson, E., and Caruh, C. 1988. Basic Exploration Geophysics. Wiley and Sons.

Suhadiyatno. 2008. Pemodelan Metode 3D dengan menggunakan Matlab. Skripsi Sarjana Jurusan Fisika Universitas Indonesia.

Sugianto, A., dan Mochamad, N.H. 2011. Survei Terpadu Daerah Panasbumi Kepahiang Kabupaten Kepahiang, Bengkulu. Bandung. Pusat Sumber Daya Geologi.

Supriyanto. 2007. Analisis Data Geofisika: Memahami Teori Inversi. Departemen Fisika-FMIPA UI. Depok.

Torkis, R. 2012. Analisa dan Pemodelan Struktur Bawah Permukaan Berdasarkan Metode Gayaberat di Daerah Prospek Panas Bumi Gunung Lawu. Skripsi. Universitas Indonesia. Depok.

\section{LAMPIRAN}




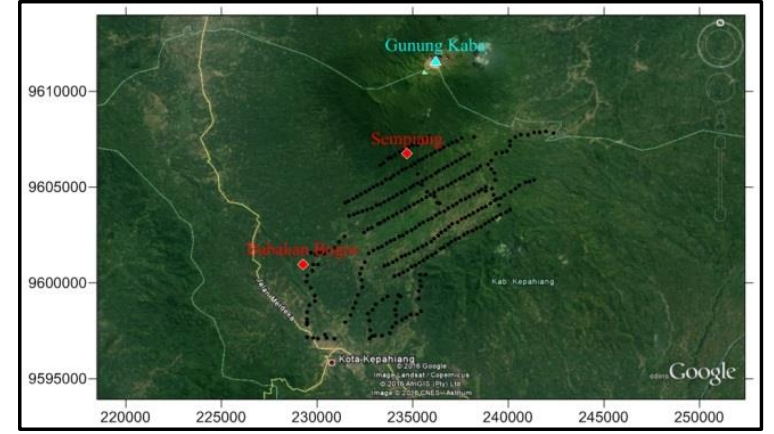

Gambar 1. Peta lokasi daerah penelitian.

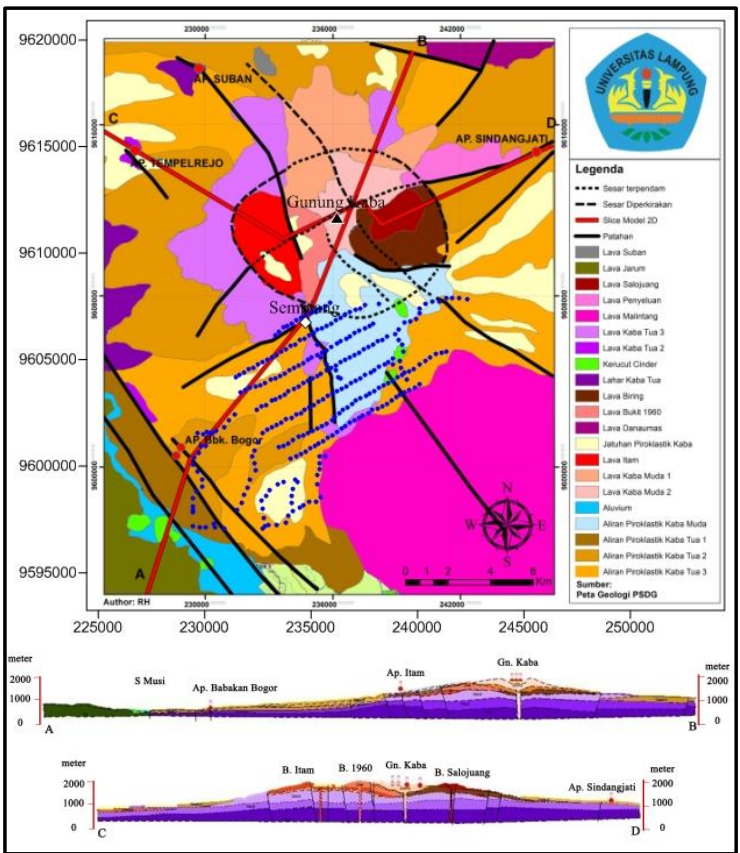

Gambar 2. Peta geologi daerah panasbumi Kepahiang (Sugianto, 2011).

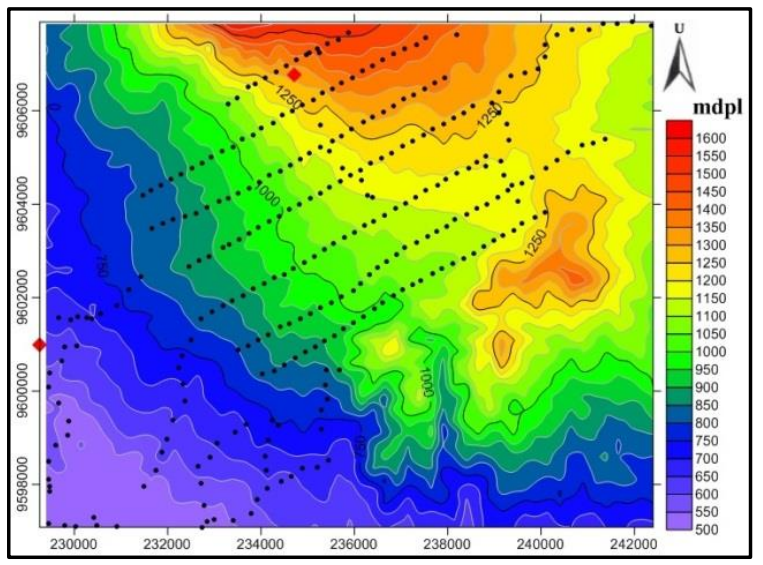

Gambar 16. Peta topografi daerah penelitian.

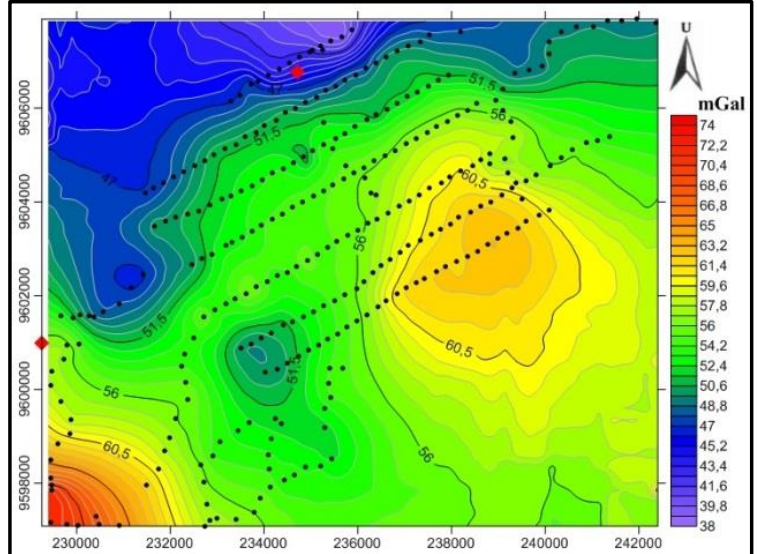

Gambar 17. Peta anomali Bouguer lengkap daerah penelitian.

Tabel 4. Hasil Perhitungan analisis spektrum

\begin{tabular}{|l|c|c|c|c|l|c|}
\hline \multirow{2}{*}{ Nama } & \multicolumn{2}{|c|}{ Batas Regional } & \multicolumn{2}{c|}{ Batas Residual } & \multirow{2}{*}{$\begin{array}{c}\text { Lebar } \\
\text { Jendela }\end{array}$} & \multirow{2}{*}{ Kc } \\
\cline { 2 - 6 } & meter & \multicolumn{1}{c}{ c } & meter & c & \\
\hline Line A & 2862.6 & 7.3849 & 650.96 & 5.1127 & 21.989 & 0.0012 \\
\hline Line B & 3045.7 & 7.0674 & 630.37 & 4.9318 & 21.989 & 0.0012 \\
\hline Line C & 2606.4 & 7.1326 & 404.55 & 3.8427 & 14.659 & 0.0017 \\
\hline Line D & 3581.5 & 7.2415 & 1539.4 & 5.607 & 17.658 & 0.0014 \\
\hline Rata-rata & $\mathbf{3 0 2 4 . 1}$ & 7.2 & $\mathbf{8 0 6 . 3}$ & $\mathbf{4 . 9}$ & $\mathbf{1 9}$ & 0.0014 \\
\hline
\end{tabular}

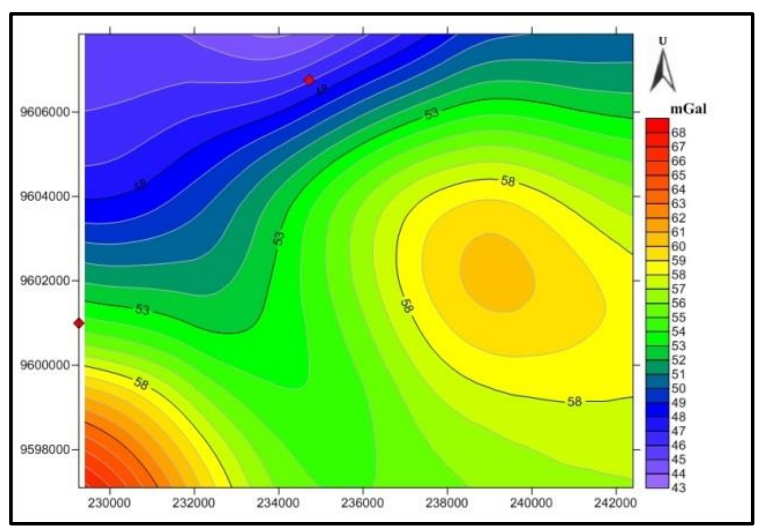

Gambar 23. Peta anomali regional daerah penelitian.

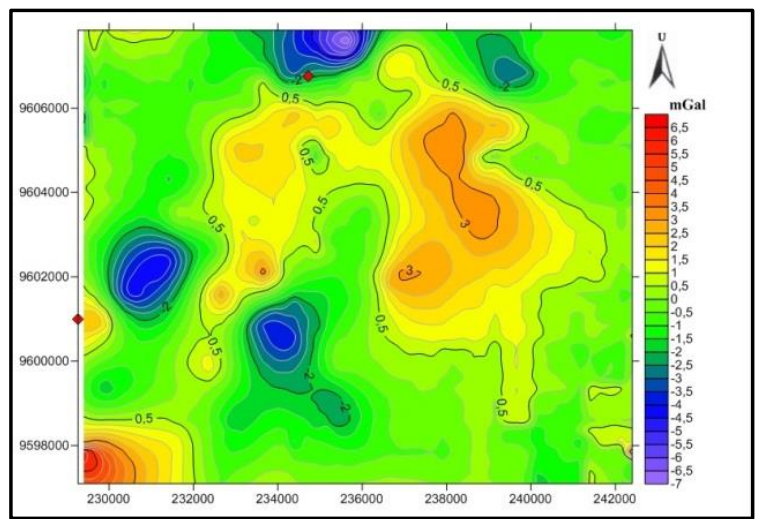

Gambar 24. Peta anomali residual daerah penelitian. 


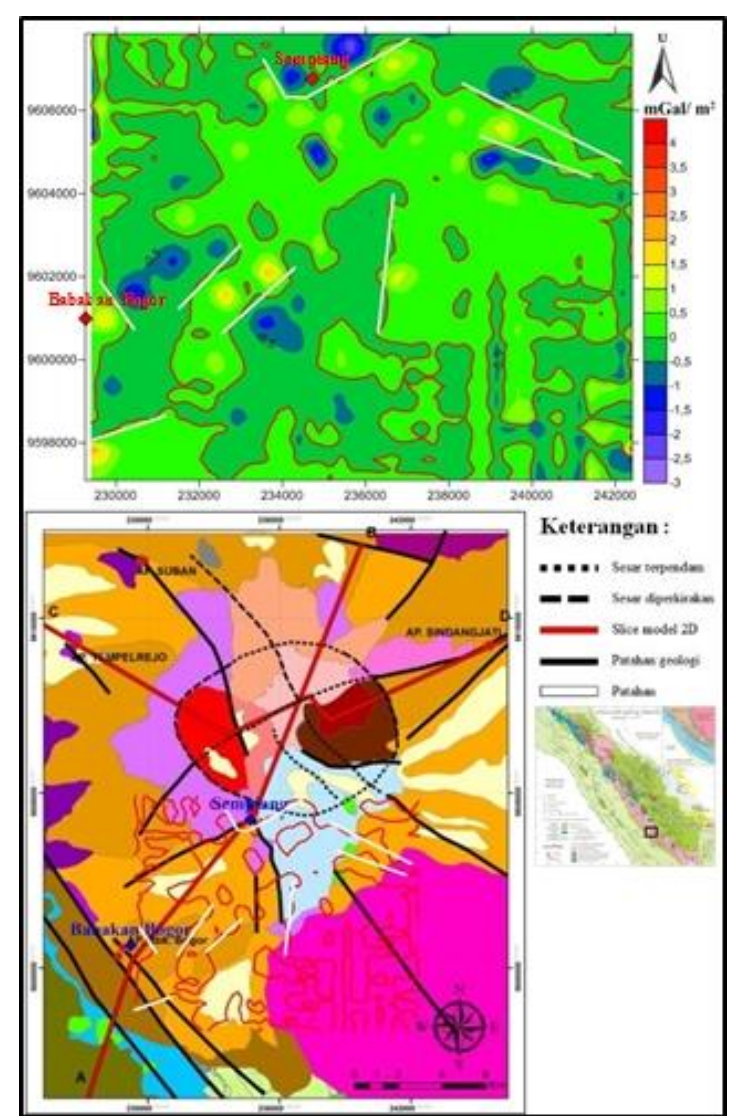

Gambar 25. Peta SVD anomali Bouguer lengkap dan yang dioverlay terhadap peta geologi.

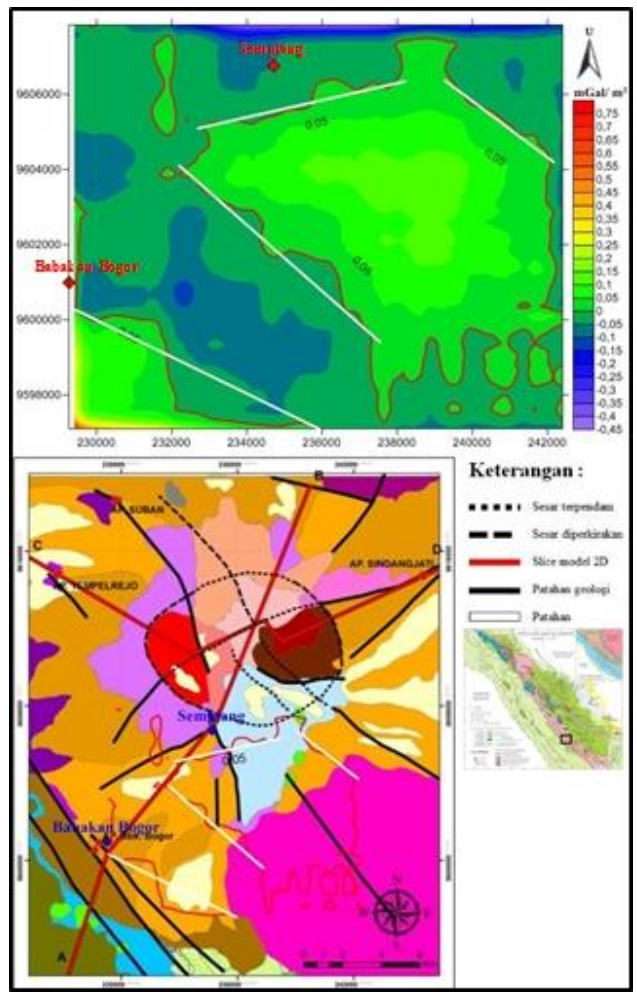

Gambar 26. Peta SVD anomali regional dan yang dioverlay terhadap peta geologi.

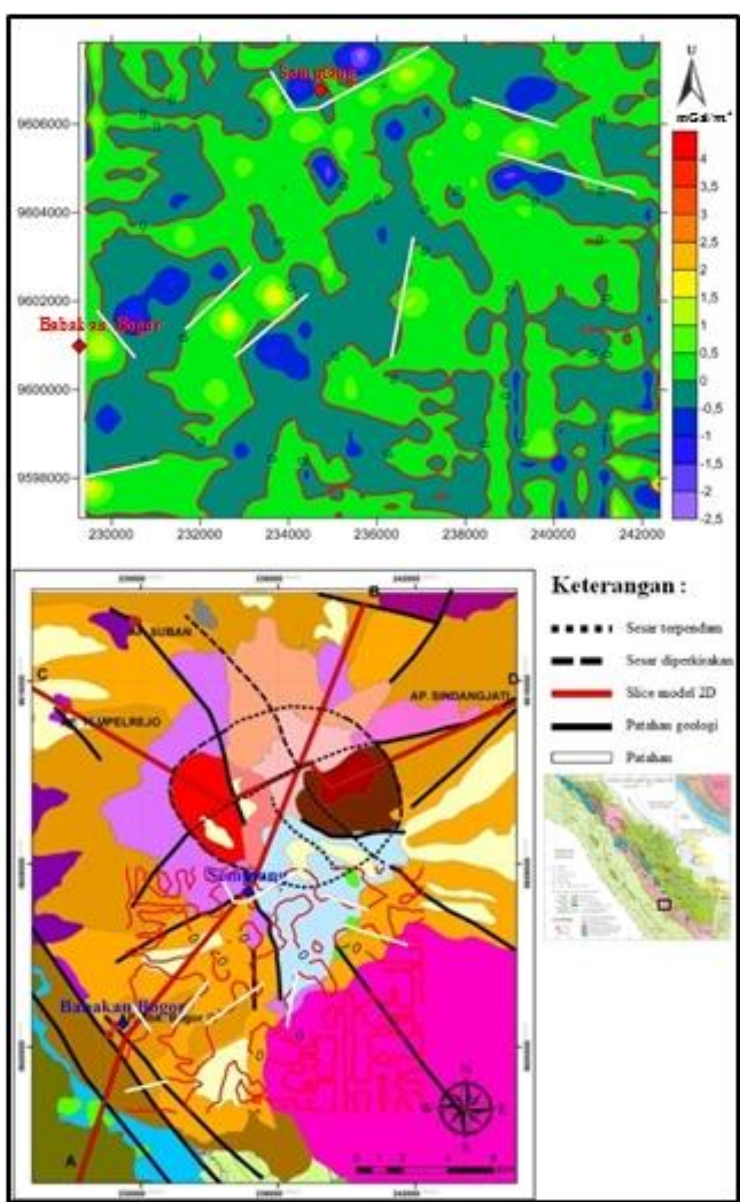

Gambar 27. Peta SVD anomali residual dan yang dioverlay terhadap peta geologi.

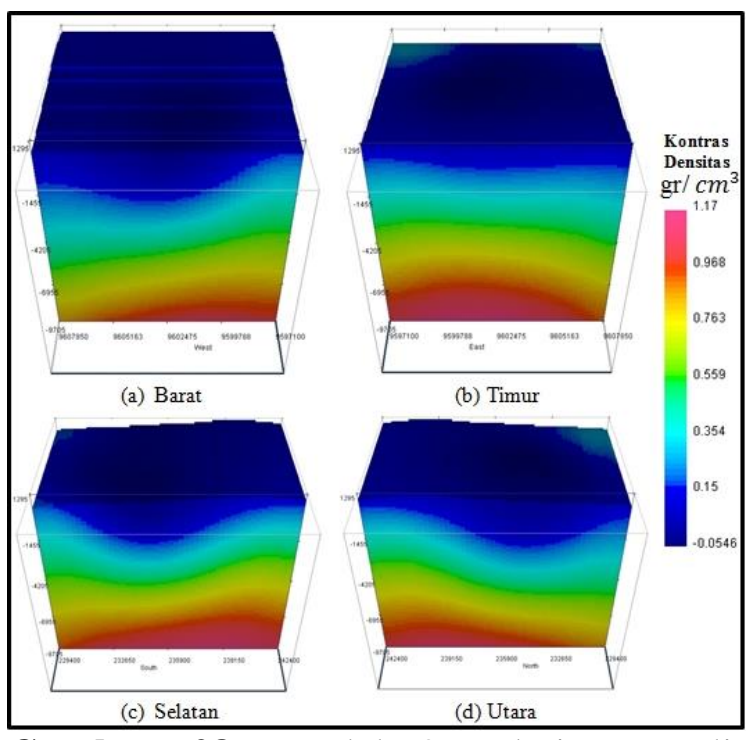

Gambar 28. Model 3D dari anomali Bouguer lengkap tampak arah (a) Barat, (b) Timur, (c) Selatan dan (d) Utara. 


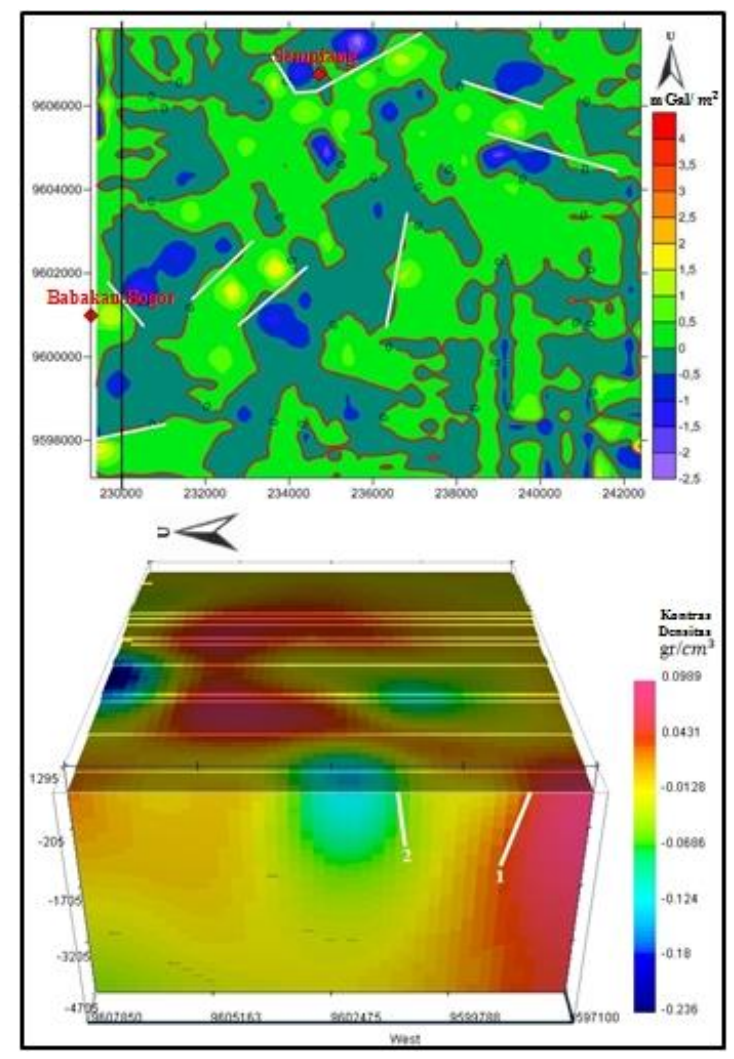

Gambar 29. Struktur patahan yang terletak di arah barat dan barat daya pada peta SVD anomali residual dan model 3D anomali residual.

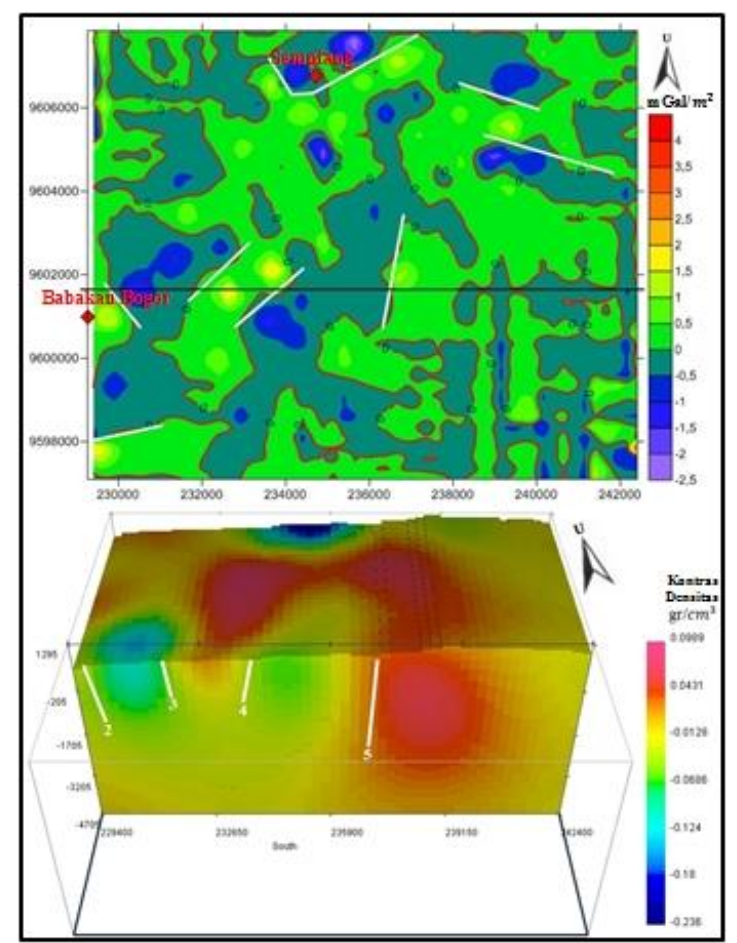

Gambar 30. Struktur patahan yang terletak di arah barat dan di bagian tengah pada peta SVD anomali residual dan model 3D anomali residual.

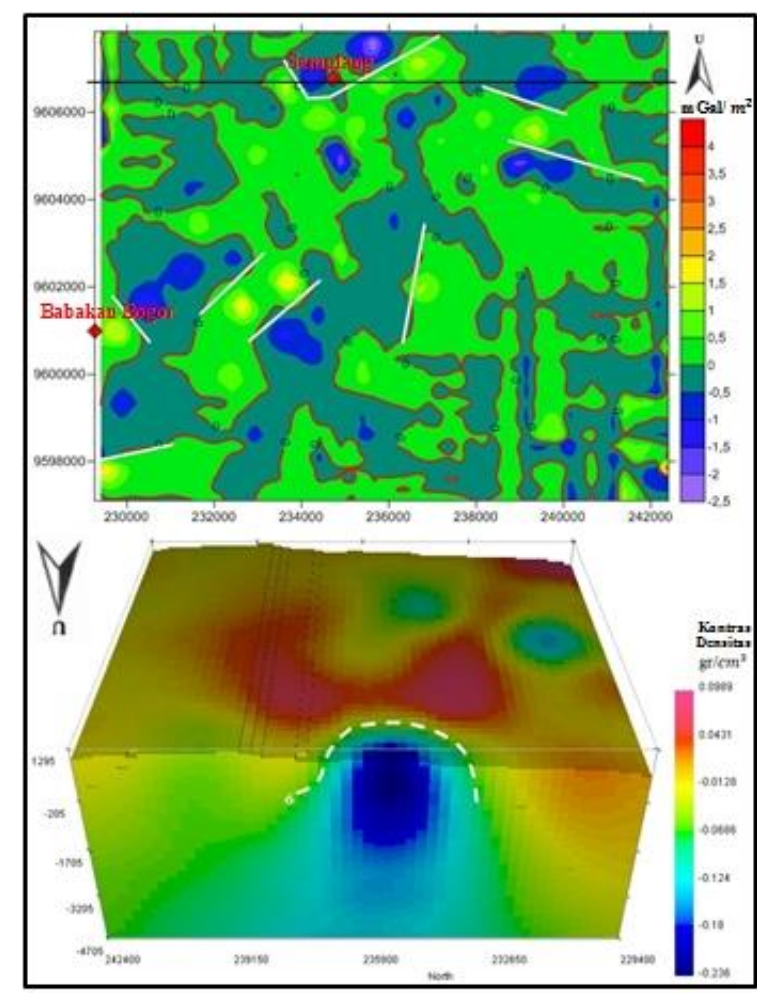

Gambar 31. Struktur patahan yang terletak di arah utara pada peta SVD anomaly residual dan model $3 \mathrm{D}$ anomali residual.

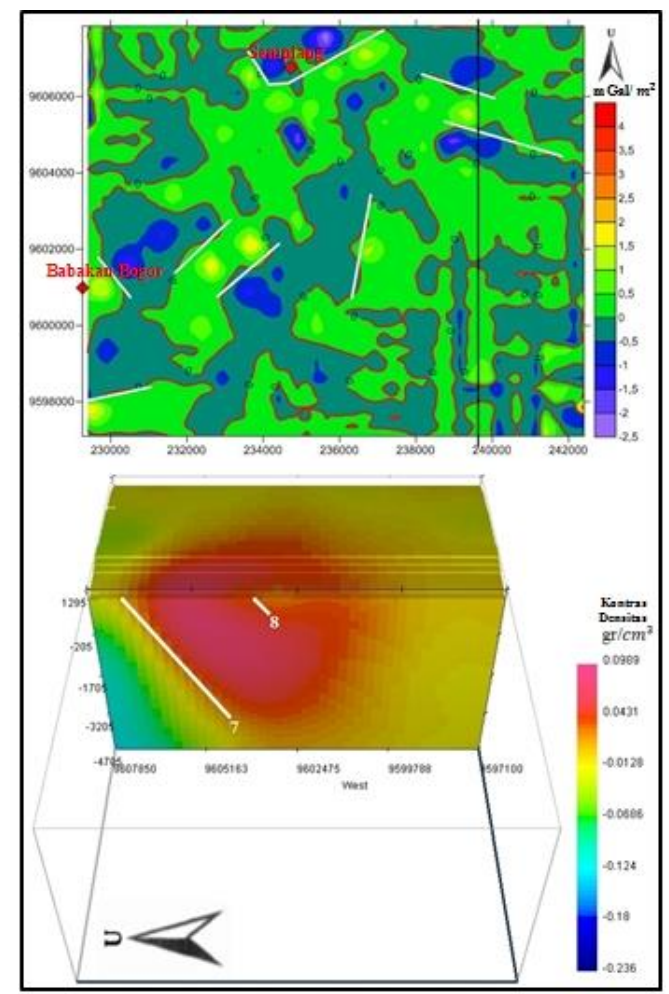

Gambar 32. Struktur patahan yang terletak di arah timur laut pada peta SVD anomali residual dan model 3D anomali residual. 


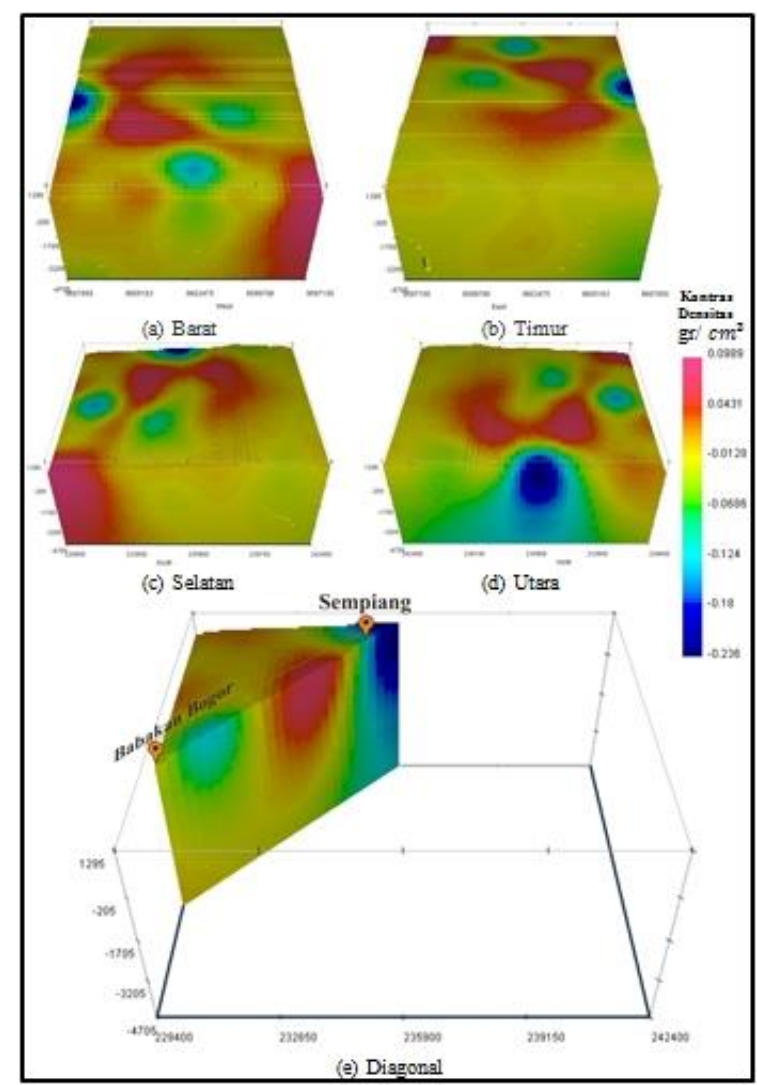

Gambar 33. Model 3D dari anomali Bouguer lengkap tampak arah (a) Barat, (b) Timur, (c) Selatan, (d) Utara dan (e) Diagonal.

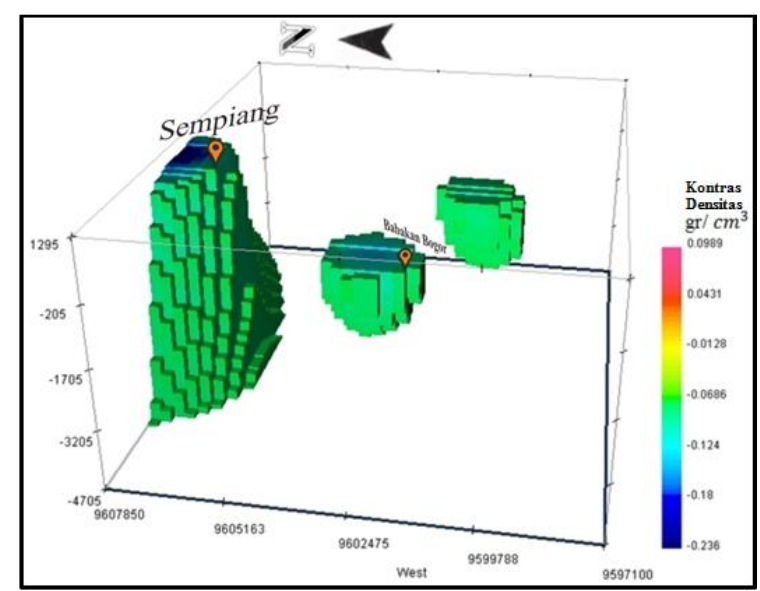

Gambar 34. Model 3D distribusi densitas hasil inversi anomali residual daerah penelitian yang diduga sebagai reservoar.

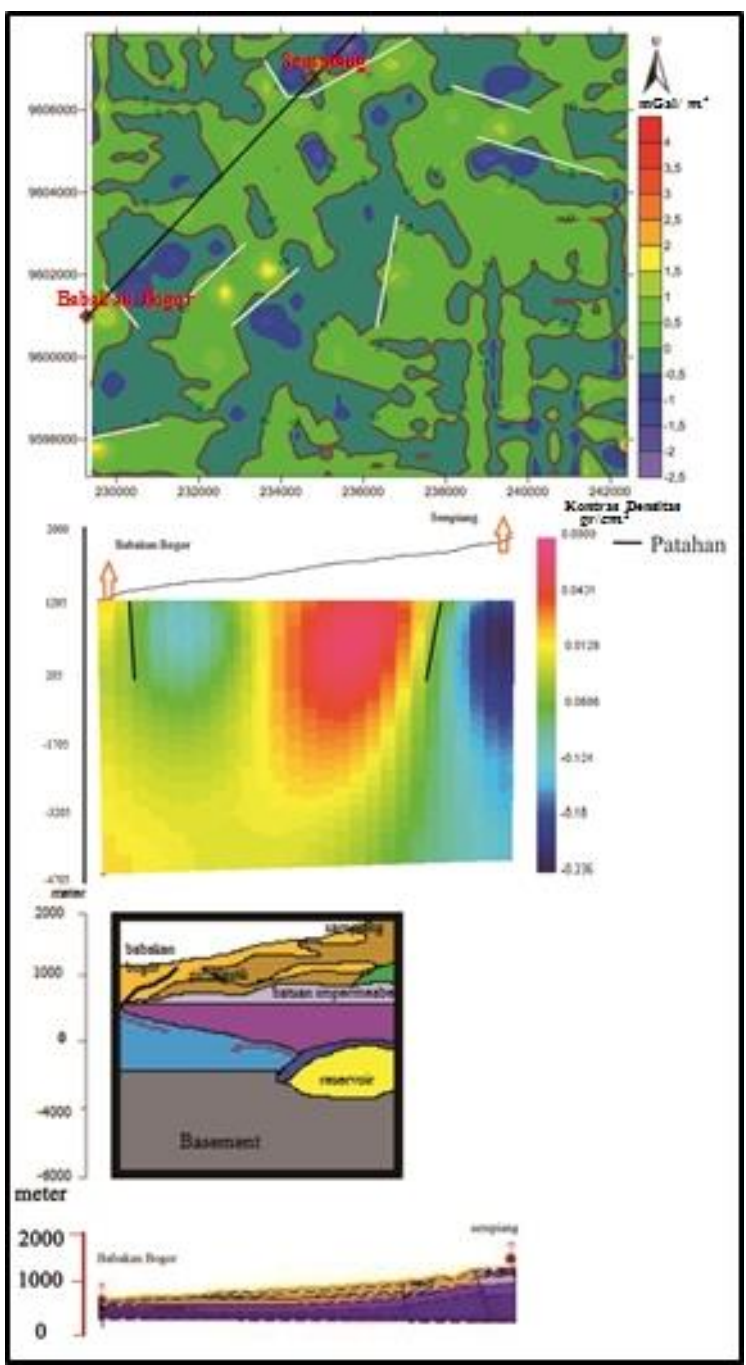

Gambar 35. Model tentatif sistem panasbumi daerah penelitian. 